\title{
Rickettsia felis, an Emerging Flea-Borne Rickettsiosis
}

\author{
Lisa D. Brown ${ }^{1} \cdot$ Kevin R. Macaluso ${ }^{1}$
}

Published online: 23 April 2016

(C) The Author(s) 2016. This article is published with open access at Springerlink.com

\begin{abstract}
Rickettsia felis is an emerging insect-borne rickettsial pathogen and the causative agent of flea-borne spotted fever. First described as a human pathogen from the USA in 1991, R. felis is now identified throughout the world and considered a common cause of fever in Africa. The cosmopolitan distribution of this pathogen is credited to the equally widespread occurrence of cat fleas (Ctenocephalides felis), the primary vector and reservoir of $R$. felis. Although $R$. felis is a relatively new member of the pathogenic Rickettsia, limited knowledge of basic $R$. felis biology continues to hinder research progression of this unique bacterium. This is a comprehensive review examining what is known and unknown relative to $R$. felis transmission biology, epidemiology of the disease, and genetics, with an insight into areas of needed investigation.
\end{abstract}

Keywords Rickettsia felis · Flea-borne spotted fever . Transmission biology $\cdot$ Epidemiology $\cdot$ Genetic diversity

\section{Introduction}

Insect-borne rickettsiae are among the most influential zoonotic pathogens in human populations throughout the world, with both historic (e.g., louse-borne epidemic typhus during Napoleon's retreat from Moscow) [1] and current (e.g., reemergence of flea-borne endemic typhus in southern

This article is part of the Topical Collection on Rickettsia

Kevin R. Macaluso

kmacaluso@vetmed.lsu.edu

1 Department of Pathobiological Sciences, School of Veterinary Medicine, Louisiana State University, Skip Bertman Drive, SVM-3213, Baton Rouge, LA 70803, USA
California and Texas) [2,3] outbreaks. Recently, a third insect-borne rickettsial pathogen, Rickettsia felis, has progressed from a sporadic disease in the USA to a common cause of fever in Africa [4]. First described in 1990 from colonized cat fleas (Ctenocephalides felis) [5], this intracellular Gram-negative bacterium was associated with human disease by 1991 [6]. Many years passed before the species itself was formally validated by molecular criteria in 2001, and isolation of the reference strain (Marseille-URRWXCal2) from cat fleas was completed shortly thereafter in 2002 $[7,8]$. The definitive description of $R$. felis as the causative agent of flea-borne spotted fever has dramatically increased the appearance of this pathogen in the literature, with roughly 315 peer-reviewed articles currently and more than $90 \%$ of which were published after 2002. The ease of molecular tools, specifically polymerase chain reaction (PCR), to detect pathogens from around the globe has confirmed $R$. felis infections from every continent except Antarctica [4, 6, 9]. Within the last decade, several advances have been made towards the understanding of basic $R$. felis biology (e.g., genomics and pathogenicity), yet some deficiencies (e.g., transmission mechanisms, epidemiology, and species diversity) remain and continue to hinder investigative advances for this universal emerging pathogen.

\section{Transmission Biology of $\boldsymbol{R} \cdot$ felis}

Following the initial detection of $R$. felis from an isolated cat flea colony, several other commercial and institutional organizations confirmed the presence of $R$. felis in additional laboratory-reared cat flea colonies (reviewed in [10]). Sustained R. felis infections within cat flea populations were first postulated to occur through stable vertical transmission based on the detection of rickettsiae in flea reproductive 
tissues [11]. Later reports using PCR analyses confirmed vertical transmission of $R$. felis in colonized cat fleas in both freshly deposited flea eggs (transovarial transmission) and newly emerged, unfed adult fleas (transstadial transmission) $[11,12]$. Subsequently, the cat flea was considered not only the primary vector of $R$. felis but also the reservoir host due to the maintenance of infection solely within the vector population [12]. Although vertical transmission has been demonstrated, prevalence of $R$. felis among cat flea colonies exhibits tremendous variability. For example, prevalence of $R$. felis-infection in adult cat fleas from a single colony ranged from 35 to $96 \%$ over the course of 1 year [13], while comparison of $F_{1}$ infection rates from distinct $R$. felis-infected cat flea colonies may range from 0 to $100 \%$ based on unknown mechanisms [10]. An inverse correlation was observed between colony $R$. felis-infection prevalence and $R$. felis-infection load in individual cat-fed fleas, suggesting that vertical transmission of $R$. felis is a maintenance strategy for persistence within cat flea populations [13]; however, vertical transmission efficiency of $R$. felis in cat fleas fed on bovine blood, as opposed to cat-fed colonies, was shown to severely diminish after 12 consecutive generations [14]. The inefficient transfer of $R$. felis from adult to progeny fleas was potentially linked to the vertebrate blood source, but cat fleas lack true host specificity and $R$. felis-infected arthropods have been recovered from numerous vertebrate species (e.g., cats, dogs, rodents, opossums, hedgehogs, horses, sheep, goats, gerbils, and monkeys) [4, 10, 15]. Given that vertical transmission of $R$. felis is not $100 \%$ efficient, it is probable that horizontal amplification is required for maintenance of this pathogen within vector populations.

Further studies with cat flea colonies lacking a constitutive R. felis-infection demonstrated favorable host-pathogen associations for horizontal transmission. The initial report showed that uninfected cat fleas were able to acquire $R$. felis by feeding on a simulated infectious bloodmeal, and this newly acquired infection persists the remainder of the vectors' lifespan [16]. Following $R$. felis acquisition in previously uninfected cat fleas, the infection then disseminates from the gut to the hemocoel and other tissues before reaching the salivary glands [17•]. Subsequent transmission of $R$. felis to vertebrate hosts is based on serum samples positive to rickettsial antigen and to a lesser extent PCR-positive tissue samples, including blood, resulting from exposure to infected cat fleas (reviewed in [10]). Ultimately, horizontal transmission of $R$. felis was demonstrated through a shared bloodmeal between $R$. felis-infected and uninfected cat fleas in an artificial host system [18•]. Contrary to other vector-borne pathogens, there appears to be no correlation between rickettsial distribution in flea tissues and distinct transmission routes, i.e., horizontal transmission events occur well before the spread of $R$. felis to flea salivary glands (authors' unpublished data).

The majority of our current understanding of the life cycle of $R$. felis in nature is derived from R. felis/C. felis laboratory models. The dilemma in this transmission cycle is the subsequent acquisition of viable $R$. felis by cat fleas from vertebrate hosts to complete the "flea to mammal to flea" succession comparable to other insect-borne rickettsial pathogens. Transmission of $R$. felis from cat fleas to vertebrate hosts is presumed to occur through infectious flea bite and potentially infected flea feces, which are also comprised of rickettsiae [16]. Among the mammalian species found to be seropositive or PCR-positive for R. felis in nature include cats, dogs, opossums, raccoons, rodents, and humans [10, 19-22]. A definitive mammalian host with a systemic $R$. felis infection has not been identified and may vary by geographic location (e.g., lack of marsupials in Africa, Asia, and Europe) and distribution of arthropod vectors (e.g., sites that have few, if any, cat fleas) $[10,23]$. A recent study generated $R$. felis-infected $\mathrm{BALB} / \mathrm{c}$ mice via an artificial route, and subsequently produced infectious Anopheles gambiae mosquitoes that caused transient rickettsemia in naïve mice [24]; nevertheless, naturally infected mammalian blood or tissues have never been shown as a source of $R$. felis infection from vertebrate to arthropod hosts.

The transmission biology of flea-borne spotted fever is complicated further by the progressive accumulation of field surveys reporting molecular detection of this infectious agent from other vectors, i.e., more than 40 additional species of fleas, ticks, mites, and mosquitoes (Table 1) [4]. Given the infrequency of a systemic vertebrate infection, the presence of $R$. felis in these additional arthropod species is unclear. Successful transmission of pathogens between actively blood-feeding arthropods in the absence of a disseminated vertebrate infection has been demonstrated (reviewed in [25]). This transmission event, referred to as co-feeding, is reliant on the temporal and spatial dynamics of infected and uninfected arthropods as they blood feed. The infected arthropod is both the vector and the reservoir for the pathogen, while the vertebrate acts as a conduit for infection of naïve arthropods. The potential for co-feeding transmission of $R$. felis between cat fleas was demonstrated with the use of a shared bloodmeal in an artificial host system [18•]. Recently, both intra- and interspecific transmission of $R$. felis between co-feeding arthropods on a vertebrate host was demonstrated (Fig. 1C and D) [26•]. Analyses revealed that infected cat fleas transmitted $R$. felis to naïve cat fleas and Oriental rat fleas (Xenopsylla cheopis) via flea bite on a non-rickettsemic vertebrate host [26•]. Also, cat fleas infected by co-feeding were infectious to newly emerged uninfected cat fleas in an artificial system (Fig. 1E) [26•]. Furthermore, a stochastic model was utilized to demonstrate that co-feeding is sufficient to explain the enzootic spread of $R$. felis among populations of the biological vector [26•]. These results implicate cat fleas in the spread of $R$. felis among different vectors, and the demonstration of co-feeding transmission of $R$. felis through a vertebrate host represents a novel transmission paradigm for insect-borne Rickettsia. 
Table 1 Geographic distribution of $R$. felis in wild-caught arthropods since 2009 review [10]

\section{Co}

Albania
Algeria

Australia

Brazil

Chile

China

Colombia

Costa Rica

Côte d'Ivoire

Cyprus

Czech Republic

Democratic Republic of Congo (Kinshasa) Democratic Republic of Congo
(Ituri)

Ethiopia

France

Gabon

Guatemala

Hungary

Indonesia

Italy

Ivory Coast

Kenya

Korea

Laos
Vector

Prevalence of

Reference infection

$\begin{array}{ll}3 \%(10 / 371) & {[71]} \\ 96 \%(316 / 331) & {[72]} \\ 15 \%(10 / 69) & {[73]} \\ \mathrm{ND} & {[74]} \\ \mathrm{ND} & {[55]} \\ \mathrm{ND} & {[75]} \\ 38 \%(268 / 701) & {[61]} \\ 14 \%(1 / 7) & {[76} \\ \mathrm{ND} & {[77]} \\ \mathrm{ND} & {[78]} \\ \mathrm{ND} & {[79]} \\ \mathrm{ND} & {[80]} \\ 95 \%(57 / 60) & {[81]} \\ 10 \%(15 / 146) & \\ 16 \%(6 / 37) & \\ 6 \%(25 / 428) & \end{array}$

ND

Pulex irritans

C. felis

ND

C. felis

Anopheles gambiae

ND

$1 \%(1 / 77)$

X. cheopis

Fleas

$1 \%(4 / 400)$

$18 \%(6 / 33)$

C. felis

$95 \%(37 / 39)$

C. canis

C. felis

C. felis

Leptopsylla aethiopica

Echidnophaga gallinacea

Fleas

C. felis

P. irritans

Fleas

$42 \%(10 / 24)$

$57 \%(13 / 23)$

$23 \%(15 / 64)$

$9 \%(1 / 11)$

$5 \%(1 / 21)$

$21 \%(63 / 303)$

[90]

$100 \%(3 / 3)$

$43 \%(23 / 53)$

ND

A. erinacei

$99 \%(128 / 129)$

A. erinacei

$11 \%(2 / 19)$

[94]

$3 \%(3 / 96)$

[95]

C. felis

ND

[83]

C. felis

ND

X. cheopis

ND

C. felis

$26 \%(34 / 132)$

Fleas

C. felis

ND

$12 \%(38 / 320)$

[99]

C. felis

C. canis

X. cheopis, C. felis, C. canis,

P. irritans, E. gallinacea

Ctenophthalmus congeneroides, Stenoponia sidimi, Rhadinopsylla insolita

C. canis, C. felis, Ctenocephalides orientis
$31 \%(9 / 29)$

$50 \%(1 / 2)$

ND

ND

$59 \%(13 / 22)$ 
Table 1 (continued)

\begin{tabular}{|c|c|c|c|}
\hline Country & Vector & $\begin{array}{l}\text { Prevalence of } \\
\text { infection }\end{array}$ & Reference \\
\hline \multirow[t]{2}{*}{ Lebanon } & C. felis & $16 \%(17 / 104)$ & [104] \\
\hline & C. felis & $44 \%(8 / 18)$ & [105] \\
\hline \multirow[t]{3}{*}{ Malaysia } & C. felis & $32 \%(57 / 177)$ & {$[22]$} \\
\hline & C. felis & $4 \%(4 / 95)$ & [106] \\
\hline & C. fels & $75 \%(337 / 450)$ & [107] \\
\hline \multirow[t]{2}{*}{ Mexico } & C. felis & $25 \%(1 / 4)$ & [108] \\
\hline & Polygenis odiosus & $33 \%(1 / 3)$ & \\
\hline Morocco & Fleas & $20 \%(112 / 554)$ & [109] \\
\hline New Caledonia & C. felis & $81 \%(17 / 21)$ & {$[110]$} \\
\hline Netherlands & C. canis, C. felis & ND & [111] \\
\hline Panama & C. felis & $35 \%(7 / 20)$ & [112] \\
\hline Peru & C. felis & $67 \%(2 / 3)$ & [113] \\
\hline Reunion Island & X. cheopis, Xenopsylla brasiliensis & $2 \%(5 / 205)$ & [114] \\
\hline \multirow[t]{7}{*}{ Senegal } & Aedes luteocephalus & $<1 \%(1 / 203)$ & [33] \\
\hline & Anopheles arabiensis & $1 \%(2 / 154)$ & \\
\hline & Anopheles ziemanni & $14 \%(1 / 7)$ & \\
\hline & Anopheles pharoensis & $10 \%(1 / 10)$ & \\
\hline & Anopheles funestus & $29 \%(2 / 7)$ & \\
\hline & Mansonia uniformis & $25 \%(2 / 8)$ & \\
\hline & Cimex hemipterus & $3 \%(1 / 39)$ & \\
\hline Slovakia & $\begin{array}{l}\text { Ctenophthalmus agyrtes, } \\
\text { Ctenophthalmus solutus, } \\
\text { Ctenophthalmus uncinatus, } \\
\text { Nosopsyllus fasciatus }\end{array}$ & $11 \%(34 / 315)$ & [115] \\
\hline \multirow[t]{3}{*}{ Spain } & C. felis & $26 \%(20 / 118)$ & [116] \\
\hline & C. felis & $44 \%(34 / 78)$ & {$[117]$} \\
\hline & C. felis & $3 \%(2 / 76)$ & {$[118]$} \\
\hline \multirow[t]{3}{*}{ Taiwan } & C. felis & ND & [119] \\
\hline & C. felis & $21 \%(90 / 420)$ & {$[120]$} \\
\hline & Stivalius aporus, Acropsylla episema & $1 \%(2 / 160)$ & {$[121]$} \\
\hline \multirow[t]{2}{*}{ Tunisia } & C. felis & $9 \%(2 / 22)$ & [122] \\
\hline & C. felis & $<1 \%(1 / 322)$ & [123] \\
\hline Turkey & Rhipicephalus bursa & ND & [124] \\
\hline \multirow{3}{*}{$\begin{array}{l}\text { United Republic of } \\
\text { Tanzania }\end{array}$} & C. felis & $65 \%(13 / 20)$ & [89] \\
\hline & C. canis & $71 \%(5 / 7)$ & \\
\hline & Ctenophthalmus calceatus & $25 \%(5 / 20)$ & \\
\hline \multirow[t]{8}{*}{ USA } & C. felis & ND & [125] \\
\hline & $\begin{array}{l}\text { C. felis, } P \text {. irritans, } X \text {. cheopis, } \\
\text { E. gallinacea, Diamanus montanus }\end{array}$ & ND & [126] \\
\hline & Amblyomma maculatum & ND & {$[127]$} \\
\hline & X. cheopis & ND & {$[31]$} \\
\hline & L. bostrychophila & ND & {$[41]$} \\
\hline & Carios capensis & ND & [128] \\
\hline & $\begin{array}{l}\text { C. felis, } P \text {. irritans, } X \text {. cheopis, } \\
\text { E. gallinacea, Diamanus montanus, } \\
\text { L. segnis }\end{array}$ & ND & [129] \\
\hline & Fleas & ND & [130] \\
\hline Uruguay & C. canis, C. felis & $41 \%(27 / 66)$ & [131] \\
\hline West Indies & C. felis & ND & [132] \\
\hline
\end{tabular}

$N D$ not determined 


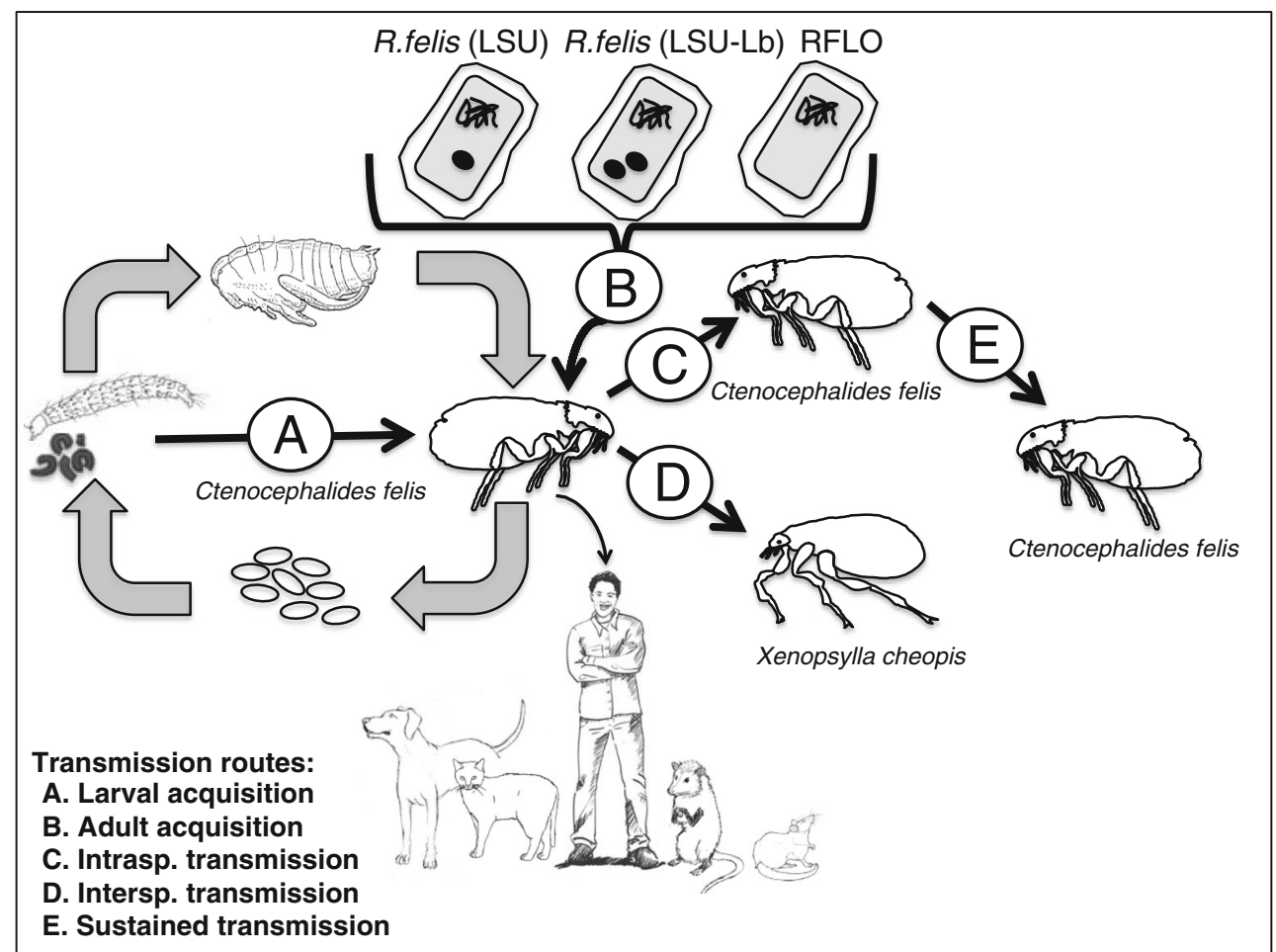

Fig. 1 The proposed and described transmission routes necessary for persistence and maintenance of $R$. felis infections within the environment. $(A)$ Vertical non-transovarial transmission, i.e., larval acquisition by infectious adult feces, of $R$. felis within cat flea colonies requires experimental confirmation. $(B)$ Adult acquisition bioassays with $R$. felis str. LSU and LSU-Lb resulted in infected cat fleas; however, acquisition bioassays with RFLOs have not been attempted. (C)
Intraspecific transmission of $R$. felis between co-feeding cat fleas was demonstrated both in an artificial system and on a vertebrate host. $(D)$ Interspecific transmission of $R$. felis between co-feeding cat fleas and rat fleas was observed on a vertebrate host. $(E)$ Sustained transmission of $R$. felis by co-feeding was demonstrated by the continuous spread of infection to newly emerged uninfected cat fleas in an artificial system over the course of 4 weeks

\section{Epidemiology of $R$. felis}

Flea-borne spotted fever is considered an emergent global threat to human health, with cases likely underestimated due to similarities in clinical signs with other febrile illnesses (e.g., fever, rash, headache, and myalgia) and limited access to appropriate laboratory tests (e.g., molecular diagnostics) $[4,10,15]$. The first human case of $R$. felis infection was misdiagnosed as flea-borne endemic typhus (Rickettsia typhi) because the available serological reagents were unable to distinguish between the two rickettsial species [6]. A retrospective investigation for $R$. felis among endemic typhus patients was initiated because field surveys revealed the presence of this agent within suspected vectors and mammalian hosts of $R$. typhi in the USA [27-29]. Comparable to endemic typhus, serological and molecular analyses have implicated cat fleas and Virginia opossums (Didelphis virginians) as respective vectors and hosts of $R$. felis in suburban regions of California and Texas [21, 27, 29]. The suburban cycle of endemic typhus is unique to the USA due to urban expansion into suburban environments and most likely supplementary to the classic association of $R$. typh $i$ with rat fleas and commensal rats (Rattus sp.) [30]. Interestingly, a recent survey revealed a higher prevalence of R. felis among Oriental rat fleas and Norwegian rats (Rattus norvegicus) than $R$. typhi in endemic typhus areas of Los Angeles [31]. It is unclear whether this urban focus was newly established or represents an expansion of a persistent lowlevel exposure rate of rat populations to $R$. felis-infected fleas. The vulnerability of human populations to flea-borne rickettsiae is of particular concern in developed countries where aggressive pest management programs may not control for ectoparasites, which can result in the relocation of arthropods to new hosts (e.g., humans and their pets) following rodent extermination. Given the indiscriminate feeding habits of cat fleas [15], $R$. felis is essentially a household rickettsiosis in human populations where peri-domestic animals (e.g., cats, dogs, opossums) are in close contact.

Much of the latest work concerning the epidemiology of R. felis has been conducted almost exclusively in Africa due to the considerable frequency of flea-borne spotted fever in hospitalized febrile patients. In sub-Saharan Africa, R. felis is described as a common (3-15\%) cause of illness among patients with "fever of unknown origin" in malaria- 
endemic regions [20, 32, 33]. Remarkably, the incidence of human $R$. felis infections was higher than that of malaria in two of the studied villages of Senegal [32]. This high proportion of $R$. felis infections reported within the last 5 years is in stark contrast to the total number of infections $(\sim 100$ human cases) documented worldwide [4]. Again, although $R$. felis is classified as an emerging pathogen, it is unclear whether this increased incidence in Africa reflects an overall trend or represents an endemic state previously unknown for this disease. Commonalities (e.g., geographic distribution, seasonality, target population, incidence of relapses or re-infections, and asymptomatic infections) were observed between the epidemiology of $R$. felis and Plasmodium falciparum infections in Africa, which were initially hypothesized to coincide because of a proposed common vector, Anopheles mosquitoes [33]. At the time of the Mediannikov et al. [33] publication, the role of Anopheles in the transmission of $R$. felis was ambiguous; however, the transmission potential of $R$. felis by A. gambiae (the primary malaria vector in sub-Saharan Africa) was recently demonstrated in a simulated model [24]. Other arthropods infected with $R$. felis in Africa include numerous species of fleas, mosquitoes, and mites, as well as an individual bed bug [33]. The vertebrate reservoir host responsible for maintenance of $R$. felis in Africa is unknown, but molecular evidence for the presence of R. felis in African apes (chimpanzees, gorillas, and bonobos) was derived from PCR-positive stool samples [34]. It was suggested that similar to malaria and other rickettsial species (e.g., louse-borne epidemic typhus), the reservoir host of R. felis in Africa might be primates, including humans [34]. As such, human fecal samples collected from two Senegalese villages with documented $R$. felis infections were PCRpositive for rickettsial DNA [35]. Conversely, it was demonstrated that for predatory apes (chimpanzees and bonobos), the ingestion of an infected prey species and associated ectoparasites might contribute significantly to the presence of parasite nucleic acids in fecal samples and caution should be used when interpreting these molecular analyses [36].

\section{Genetic Diversity of $R$. felis}

Historically, the genus Rickettsia (Rickettsiaceae) was designated as typhus group (TG) or spotted fever group (SFG) rickettsiae; however, $R$. felis displayed phenotypic oddities that confounded its categorization as either TG or SFG, e.g., association with an insect, hemolytic activity, actin-based motility, transovarial maintenance in the vector host, and serological cross-reactivity [37]. Additionally, genetic analyses of $R$. felis revealed a large genome size relative to other rickettsiae, and the presence of plasmids [38]. Combined analyses of genome and biological characteristics suggested that additional groups exist within the genus Rickettsia, including a sister clade of the SFG now known as the transitional group (TRG) and a non-pathogenic clade, thought to be basal to all other groups, called the ancestral group (AG) [37]. R. felis is a member of the TRG rickettsiae, which may explain certain anomalies (e.g., lack of a definitive mammalian host) as this bacterium continues to undergo major life history transitions.

Several strains of $R$. felis have been isolated from colonized and wild-caught arthropods [39, 40], including the non-hematophagous, parthenogenic booklouse Liposcelis bostrychophila (Insecta: Psocoptera) [41]. In the booklouse host, R. felis is an obligate mutualist required for the early development of the oocyte and is maintained $100 \%$ transovarially $[42,43]$. Given that flea-borne strains are considered facultative parasites of the vector, distinct strains of $R$. felis employ different transmission routes for sustained infection within unique arthropod populations [44]. In an effort to determine whether genetic variability determines $R$. felis host specialization, the sequenced genomes of two strains, R. felis (str. LSU-Lb) isolated from a booklice colony and $R$. felis (str. LSU) isolated from a cat flea colony, were compared to the flea-derived $R$. felis reference strain (str. URRWXCal2) [44]. Sequence analyses revealed genomic heterogeneity across the three strains of $R$. felis, suggesting that spatial isolation (str. URRWXCal2 vs. str. LSU) and potential host specialization (flea vs. booklouse) have resulted from genetic divergence [44]. Specifically, the discovery of a second, unique plasmid (pLbaR) in the R. felis str. LSU-Lb assembly provides evidence for host-specific strain variation [44]. This discovery coincides with other studies that demonstrated differences in plasmid numbers between $R$. felis strains, with some strains having no plasmids and others having two $[45,46]$. Towards this understanding, experimental bioassays were generated to determine acquisition of $R$. felis str. LSU-Lb by a colony of cat fleas, as well as subsequent prevalence and infection load dynamics (Fig. 1B). Surprisingly, not only did cat fleas become infected with the booklice strain of $R$. felis, but there were also negligible differences in prevalence and infection loads between both strains within the same cat flea colony. Additionally, similar to $R$. felis str. LSU, no overt fitness effect on cat fleas infected with $R$. felis str. LSU-Lb was observed, including the production and development of $F_{1}$ progeny (authors' unpublished data). Thus, the selective forces operating on $R$. felis genomes from strains associated with different arthropod vectors remain unknown and require further examination.

Within the last decade, numerous reports have identified R. felis-like organisms (RFLOs) in different arthropods, including cat fleas (Table 2), throughout the world based on multilocus sequence typing (MLST). A gene sequencedbased criterion was proposed for the identification of Rickettsia isolates at the genus, group, and species level [47]. As such, the number of newly identified Rickettsia, specifically RFLOs, has dramatically increased since this recent 
Table 2 Geographic distribution of RFLO in wild-caught arthropods

\begin{tabular}{|c|c|c|c|}
\hline Country & Vector & $\begin{array}{l}\text { Prevalence of } \\
\text { infection }\end{array}$ & Reference \\
\hline Brazil & Ctenocephalides felis & ND & {$[78]$} \\
\hline China & Eulaelaps stabularis & ND & {$[80]$} \\
\hline Côte d'Ivoire & Anopheles gambiae, Anopheles melas & $7 \%(5 / 77)$ & {$[85]$} \\
\hline Costa Rica & C. felis & ND & [83] \\
\hline Croatia & Haemaphysalis sulcata & $23 \%(23 / 101)$ & [133] \\
\hline Czech Republic & Fleas & $3 \%(1 / 33)$ & {$[87]$} \\
\hline Ecuador & C. felis & $100 \%(8 / 8)$ & {$[134]$} \\
\hline \multirow[t]{2}{*}{ Egypt } & Echidnophaga gallinacea & $100 \%(12 / 12)$ & [135] \\
\hline & Ornithonyssus bacoti & ND & [136] \\
\hline France & Archaeopsylla erinacei & $50 \%(2 / 4)$ & [105] \\
\hline \multirow[t]{3}{*}{ Gabon } & Ctencephalides canis & $100 \%(12 / 12)$ & {$[105]$} \\
\hline & An. gambiae & $1 \%(1 / 88)$ & {$[85]$} \\
\hline & An. melas & $9 \%(6 / 67)$ & \\
\hline Germany & Archaeopsylla erinacei & $96 \%(144 / 150)$ & {$[137]$} \\
\hline Hungary & Pulex irritans & ND & [96] \\
\hline \multirow[t]{2}{*}{ India } & Fleas & $78 \%(7 / 9)$ & {$[138]$} \\
\hline & C. felis & $73 \%(56 / 77)$ & [139] \\
\hline Iran & Pediobius rotundatus & $20 \%(1 / 5)$ & {$[140]$} \\
\hline Israel & Xenopsylla ramesis, Synosternus cleopatrae & ND & [141] \\
\hline Japan & C. felis & $39 \%(26 / 67)$ & [142] \\
\hline \multirow[t]{2}{*}{ Kenya } & $\begin{array}{l}\text { Xenopsylla cheopis, C. felis, C. canis, P. irritans, } \\
\quad \text { E. gallinacea }\end{array}$ & ND & {$[49 \bullet]$} \\
\hline & C. canis, C. felis & ND & [143] \\
\hline Malaysia & C. felis & $3 \%(6 / 209)$ & {$[144]$} \\
\hline Peru & C. felis & $96 \%(71 / 74)$ & [145] \\
\hline Portugal & Ornithodoros erraticus & ND & [146] \\
\hline \multirow[t]{3}{*}{ Senegal } & Synosternus pallidus & $91 \%(31 / 34)$ & {$[147]$} \\
\hline & Glossina morsitans & $100 \%(78 / 78)$ & [148] \\
\hline & C. felis & $17 \%(5 / 29)$ & {$[50]$} \\
\hline Slovakia & $\begin{array}{l}\text { Ctenophthalmus agyrtes, Ctenophthalmus solutus, } \\
\text { Ctenophthalmus uncinatus, Nosopsyllus fasciatus }\end{array}$ & $11 \%(34 / 315)$ & [115] \\
\hline Spain & C. canis, C. felis & $28 \%(25 / 88)$ & [149] \\
\hline Taiwan & $\begin{array}{l}\text { Leptotrombidium chigger mites, Ixodes granulatus, } \\
\text { Mesostigmata mites }\end{array}$ & ND & {$[150]$} \\
\hline Thailand & C. canis, C. felis & $43 \%(66 / 152)$ & [151] \\
\hline $\begin{array}{l}\text { Thai-Myanmar } \\
\text { border }\end{array}$ & C. canis, C. felis & $4 \%(4 / 54)$ & {$[152]$} \\
\hline \multirow[t]{3}{*}{ USA } & C. felis & $100 \%(19 / 19)$ & [153] \\
\hline & C. felis & ND & {$[154]$} \\
\hline & Carios capensis & ND & {$[128]$} \\
\hline
\end{tabular}

$N D$ not determined designation. The proposed genetic guidelines rely on similarities (i.e., percent homology) in the sequences of the $16 \mathrm{~S}$ rRNA (rrs) $(\geq 99.8 \%)$ gene and four protein-coding genes, the gltA ( $\geq 99.9 \%)$, ompA $(\geq 98.8 \%)$, and ompB $(\geq 99.2 \%)$ genes and gene D ( $\geq 99.3 \%)$ to existing Rickettsia species [47]. The concern with this approach is that $0.2 \%$ divergence in the rrs gene is the borderline for separation of 2 Rickettsia species, whereas $1 \%$ divergence is known to mark the borders of naturally occurring bacterial species [48]. For example, two recently described Rickettsia species isolated from cat fleas, Candidatus Rickettsia asemboensis and Candidatus Rickettsia senegalensis, showed 99.5 and $99.65 \%$ similarity 
to the $r r s$ gene in validated species of $R$. felis, respectively $[49 \cdot, 50]$. Given the potential for genetic diversity of $R$. felis isolates due to spatial isolation, a more suitable approach to justify the separation of RFLOs into species may be to seek ecological, genomic, or phenotypic differences among the major clusters resolved by MLST [48]. Recently, the whole-genome of Candidatus Rickettsia asemboensis was sequenced [51], and future comparative analyses may reveal genotypic differences responsible for phenotypic characteristics.

\section{Prospective Research for $\boldsymbol{R}$. felis}

The transmission routes required for persistence and maintenance of $R$. felis infections in endemic-disease foci remains unclear (Fig. 1A-E). Excretion of viable rickettsiae in the feces of infected arthropods is crucial in transmission cycles for both louse-borne epidemic typhus (Rickettsia prowazekii) and flea-borne endemic typhus (R. typhi) [30, 52]. The direct inoculation of fecal bacteria by scratching at the bite site constitutes as a persistent source of infection from arthropod to vertebrate hosts. Although $R$. felis-infected cat fleas generate feces with detectable levels of rickettsial transcript [16], the transfer of bacteria from freshly deposited adult feces to susceptible vertebrates has not been demonstrated. Another fleaborne pathogen, Bartonella henselae, achieves successful transmission from adult fleas to their progeny via vertical non-transovarial transmission [53]. Vertical transmission of Bartonella species was demonstrated, but a previous study showed the absence of transovarial transmission of $B$. henselae within flea colonies [54]; however, when flea larvae were exposed to Bartonella-positive adult flea feces, then the larvae acquired an infection that was maintained through adulthood [53]. Thus, vertical non-transovarial transmission of $R$. felis should be tested within cat flea colonies as an additional route of pathogen maintenance in vector populations (Fig. 1A).

The lack of a description of a definitive vertebrate host impedes epidemiological studies of $R$. felis throughout the world. Doubts have been raised about whether $R$. felis transmission from mammal to arthropod occurs given the efficiency of pathogen transfer between co-feeding fleas without a systemic vertebrate infection [26•]; however, field surveys frequently identify mammalian hosts (e.g., cats, dogs, opossums, rodents) as either seropositive or PCR-positive for R. felis infections in endemic disease foci. Transmission of $R$. felis within cat flea colonies has proved variable and adaptable, with decreased colony prevalence signaling to increase infection burdens in individual fleas [13]. Thus, only occasional amplification from vertebrate hosts may be needed to enhance or maintain $R$. felis in nature. The latest reports from urban environments have emphasized the potential of domestic cats and dogs as mammalian reservoirs of $R$. felis infections
[55-61], while studies from uninhabited localities suggest the importance of rodents and opossums [22, 62]. Accordingly, it appears that a peri-domestic cycle exists for $R$. felis where components of this enzootic cycle are present, e.g., free-ranging cats and dogs, commensal rodents and opossums, and associated flea species. Future studies should address Koch's postulates to identify $R$. felis as the causative agent of vertebrate infection, specifically isolation of $R$. felis for culture from these proposed reservoir hosts.

Recently, R. felis infections in febrile and afebrile patients were diagnosed by PCR detection in human blood samples $[33,63]$; thus, it was proposed that perhaps humans could be the natural reservoir for $R$. felis, as they are for another insectborne rickettsial species ( $R$. prowazekii). The transmission cycle for $R$. prowazekii is louse to human to louse, with lice ingesting bacteria by blood-feeding on infected humans and subsequently transferring the bacterium to humans by excretion of infectious feces at the bite site [52]. A delayed complication of $R$. prowazekii is Brill-Zinsser disease, or recrudescent typhus, in which mild symptoms reappear after a latent period [52]. Humans with recrudescent typhus are still capable of infecting lice and spreading the disease [52]. Similarly, $R$. felis DNA was detected in the blood of a patient at multiple time points over a 1.5 -month interval. While this initial observation suggests episodic rickettsial infection (relapse or reinfection) in humans, these samples were taken from a child in the absence of antimicrobial therapy [32]. The occurrence of relapses or reinfections of $R$. felis should be investigated further with adult patients administered antibiotic treatment. Additional studies reported that not all patients diagnosed as PCR-positive for $R$. felis infection generated antirickettsial antibodies, which researchers proposed supports the notion of a recurrent infection [33, 64]; however, supplementary data may marginalize diagnoses of $R$. felis infection based on PCR-positive blood samples. For example, $R$. felis DNA was detected in skin swabs from healthy individuals in a Senegal village where roughly $7 \%$ of the villagers possess an $R$. felis infection $[65,66]$. This study highlights the potential for blood samples from afebrile patients to become polluted by skin surface contaminants prior to molecular analyses [65]. Furthermore, the discovery of $R$. felis in blood samples from asymptomatic persons challenges existing paradigms about pathogenic rickettsiae. Such as, the magnitude of rickettsial growth required for PCR detection in the bloodstream of patients is typically fatal, yet these afebrile individuals had no adverse symptoms [67]. Rickettsioses in febrile and afebrile persons should be confirmed by culture, but as stated previously $R$. felis has not been isolated from a vertebrate host, even in severe human cases. Thus, a human isolate must be obtained before conclusions are drawn on the role of people in $R$. felis epidemiology. 
The genetic diversity within the $R$. felis genotype appears to be vast, with different isolates shown to consist of unique individual qualities. Whether RFLOs warrant species designation is unclear, but there are disparities among this genogroup that may lead to a microbial-dependent influence on $R$. felis prevalence. For example, interspecific competition of rickettsiae in ticks is well documented, with a primary infection responsible for the interference or blocking of a secondary infection [68-70]. Thus, the high prevalence of RFLOs in areas where $R$. felis infections appear low or absent may be due to an interference event followed by perpetuation of the primary infection within a closed arthropod population. The transmission biology as well as the pathogenicity of RFLOs is unknown, but these organisms are detected in arthropods known to bite humans. Future work with RFLOs should identify, if any, phenotypic characteristics associated with genotypic diversity and focus on acquisition, dissemination, and transmission of these organisms by their respective arthropod hosts (Fig. 1B).

\section{Conclusions}

Every year, there are new reports of arthropod, animal, and human cases of $R$. felis from additional countries, and the influx of RFLOs may result in a similar trend. Active surveillance of $R$. felis infections among hospitalized febrile patients will determine when an endemic state has been reached by this emerging pathogen, as well as indicate spread to populations outside of endemic disease foci. Advance genetic analyses of Rickettsia species should include criteria for ecological, genomic and phenotypic differences in addition to sequence homology. In order to determine the specific roles of both the vertebrate and arthropod host in the transmission cycle of $R$. felis, it is critical to continue the development and implementation of molecular tools and bioassays necessary for more accurate risk assessment and efficacious control measures.

Acknowledgments This work was supported by the National Institutes of Health (AI122672).

\section{Compliance with Ethical Standards}

Conflict of Interest The authors declare that they have no conflict of interest.

Human and Animal Rights and Informed Consent This article does not contain any studies with human or animal subjects performed by any of the authors.

Open Access This article is distributed under the terms of the Creative Commons Attribution 4.0 International License (http:// creativecommons.org/licenses/by/4.0/), which permits unrestricted use, distribution, and reproduction in any medium, provided you give appropriate credit to the original author(s) and the source, provide a link to the Creative Commons license, and indicate if changes were made.

\section{References}

Papers of particular interest, published recently, have been highlighted as:

- Of importance

1. Raoult D, Dutour O, Houhamdi L, Jankauskas R, Fournier PE, Ardagna Y, et al. Evidence for louse-transmitted diseases in soldiers of Napoleon's Grand Army in Vilnius. J Infect Dis. 2006;193(1):112-20.

2. Gillespie JJ, Ammerman NC, Beier-Sexton M, Sobral BS, Azad AF. Louse- and flea-borne rickettsioses: biological and genomic analyses. Vet Res. 2009;40(2):12.

3. Blanton LS, Vohra RF, Bouyer DH, Walker DH. Reemergence of murine typhus in Galveston, Texas, USA, 2013. Emerg Infect Dis. 2015;21(3):484-6.

4. Parola P. Rickettsia felis: from a rare disease in the USA to a common cause of fever in sub-Saharan Africa. Clin Microbiol Infect. 2011;17(7):996-1000.

5. Adams JR, Schmidtmann ET, Azad AF. Infection of colonized cat fleas, Ctenocephalides felis (Bouche), with a rickettsia-like microorganism. AmJTrop Med Hyg. 1990;43(4):400-9.

6. Schriefer ME, Sacci Jr JB, Dumler JS, Bullen MG, Azad AF. Identification of a novel rickettsial infection in a patient diagnosed with murine typhus. J Clin Microbiol. 1994;32(4):949-54.

7. Bouyer DH, Stenos J, Crocquet-Valdes P, Moron CG, Popov VL, Zavala-Velazquez JE, et al. Rickettsia felis: molecular characterization of a new member of the spotted fever group. Int J Syst Evol Microbiol. 2001;51(Pt 2):339-47.

8. La Scola B, Meconi S, Fenollar F, Rolain JM, Roux V, Raoult D. Emended description of Rickettsia felis (Bouyer et al. 2001), a temperature-dependent cultured bacterium. Int J Syst Evol Microbiol. 2002;52(Pt 6):2035-41.

9. Williams M, Izzard L, Graves SR, Stenos J, Kelly JJ. First probable Australian cases of human infection with Rickettsia felis (catflea typhus). Med J Aust. 2011;194(1):41-3.

10. Reif KE, Macaluso KR. Ecology of Rickettsia felis: a review. J Med Entomol. 2009;46(4):723-36.

11. Azad AF, Sacci JB, Nelson WM, Dasch GA, Schmidtmann ET, Carl M. Genetic characterization and transovarial transmission of a typhus-like rickettsia found in cat fleas. Proc Natl Acad Sci U S A. 1992;89(1):43-6.

12. Higgins JA, Sacci Jr JB, Schriefer ME, Endris RG, Azad AF. Molecular identification of rickettsia-like microorganisms associated with colonized cat fleas (Ctenocephalides felis). Insect Mol Biol. 1994;3(1):27-33.

13. Reif KE, Stout RW, Henry GC, Foil LD, Macaluso KR. Prevalence and infection load dynamics of Rickettsia felis in actively feeding cat fleas. PLoS One. 2008;3(7):e2805.

14. Wedincamp Jr J, Foil LD. Vertical transmission of Rickettsia felis in the cat flea (Ctenocephalides felis Bouche). J Vector Ecol. 2002;27(1):96-101.

15. Perez-Osorio CE, Zavala-Velazquez JE, Arias Leon JJ, ZavalaCastro JE. Rickettsia felis as emergent global threat for humans. Emerg Infect Dis. 2008;14(7):1019-23.

16. Reif KE, Kearney MT, Foil LD, Macaluso KR. Acquisition of Rickettsia felis by cat fleas during feeding. Vector Borne Zoonotic Dis. 2011;11(7):963-8.

17. Thepparit C, Hirunkanokpun S, Popov VL, Foil LD, Macaluso KR. Dissemination of bloodmeal acquired Rickettsia felis in cat fleas, Ctenocephalides felis. Parasites Vectors. 2013;6:149. Timeline for the dissemination of newly acquired Rickettsia felis within cat fleas. 
18. Hirunkanokpun S, Thepparit C, Foil LD, Macaluso KR. Horizontal transmission of Rickettsia felis between cat fleas, Ctenocephalides felis. Mol Ecol. 2011;20(21):4577-86. First report of horizontal transmission of Rickettsia felis by cat fleas.

19. Sashika M, Abe G, Matsumoto K, Inokuma H. Molecular survey of rickettsial agents in feral raccoons (Procyon lotor) in Hokkaido, Japan. Jpn J Infect Dis. 2010;63(5):353-4.

20. Richards AL, Jiang J, Omulo S, Dare R, Abdirahman K, Ali A, et al. Human infection with Rickettsia felis, Kenya. Emerg Infect Dis. 2010;16(7):1081-6.

21. Boostrom A, Beier MS, Macaluso JA, Macaluso KR, Sprenger D, Hayes J, et al. Geographic association of Rickettsia felis-infected opossums with human murine typhus, Texas. Emerg Infect Dis. 2002;8(6):549-54.

22. Tay ST, Mokhtar AS, Low KC, Mohd Zain SN, Jeffery J, Abdul Aziz N, et al. Identification of rickettsiae from wild rats and cat fleas in Malaysia. Med Vet Entomol. 2014;28 Suppl 1:104-8.

23. Eisen RJ, Gage KL. Transmission of flea-borne zoonotic agents. Annu Rev Entomol. 2012;57:61-82.

24. Dieme C, Bechah Y, Socolovschi C, Audoly G, Berenger JM. Transmission potential of Rickettsia felis infection by Anopheles gambiae mosquitoes. Proc Natl Acad Sci U S A. 2015;112(26): 8088-93.

25. Randolph SE. Transmission of tick-borne pathogens between co-feeding ticks: Milan Labuda's enduring paradigm. Ticks Tick-Borne Dis. 2011;2(4):179-82.

26. Brown LD, Christofferson RC, Banajee KH, Del Piero F, Foil LD, Macaluso KR. Co-feeding intra- and interspecific transmission of an emerging insect-borne rickettsial pathogen. Molecular ecology. 2015(In press): First report of R. felis co-feeding transmission between arthropods on a vertebrate host.

27. Williams SG, Sacci Jr JB, Schriefer ME, Andersen EM, Fujioka $\mathrm{KK}$, Sorvillo FJ, et al. Typhus and typhuslike rickettsiae associated with opossums and their fleas in Los Angeles County, California. J Clin Microbiol. 1992;30(7):1758-62.

28. Sorvillo FJ, Gondo B, Emmons R, Ryan P, Waterman SH, Tilzer A, et al. A suburban focus of endemic typhus in Los Angeles County: association with seropositive domestic cats and opossums. AmJTrop Med Hyg. 1993;48(2):269-73.

29. Schriefer ME, Sacci Jr JB, Taylor JP, Higgins JA, Azad AF. Murine typhus: updated roles of multiple urban components and a second typhuslike rickettsia. J Med Entomol. 1994;31(5):681-5.

30. Azad AF. Epidemiology of murine typhus. Annu Rev Entomol. 1990;35:553-69.

31. Abramowicz KF, Rood MP, Krueger L, Eremeeva ME. Urban focus of Rickettsia typhi and Rickettsia felis in Los Angeles, California. Vector Borne Zoonotic Dis. 2011;11(7):979-84.

32. Socolovschi C, Mediannikov O, Sokhna C, Tall A, Diatta G, Bassene H, et al. Rickettsia felis-associated uneruptive fever, Senegal. Emerg Infect Dis. 2010;16(7):1140-2.

33. Mediannikov O, Socolovschi C, Edouard S, Fenollar F, Mouffok N, Bassene $\mathrm{H}$, et al. Common epidemiology of Rickettsia felis infection and malaria, Africa. Emerg Infect Dis. 2013;19(11):1775-83.

34. Keita AK, Socolovschi C, Ahuka-Mundeke S, Ratmanov P, Butel C, Ayouba A, et al. Molecular evidence for the presence of Rickettsia felis in the feces of wild-living African apes. PLoS One. 2013;8(2):e54679.

35. Keita AK, Fenollar F, Socolovschi C, Ratmanov P, Bassene H, Sokhna C, et al. The detection of vector-borne-disease-related DNA in human stool paves the way to large epidemiological studies. Eur J Epidemiol. 2015;30(9):1021-6.

36. De Nys HM, Madinda NF, Merkel K, Robbins M, Boesch C, Leendertz $\mathrm{FH}$, et al. A cautionary note on fecal sampling and molecular epidemiology in predatory wild great apes. Am J Primatol. 2015;77(8):833-40.

37. Gillespie JJ, Beier MS, Rahman MS, Ammerman NC, Shallom JM, Purkayastha A, et al. Plasmids and rickettsial evolution: insight from Rickettsia felis. PLoS One. 2007;2(3):e266.

38. Ogata H, Renesto P, Audic S, Robert C, Blanc G, Fournier PE, et al. The genome sequence of Rickettsia felis identifies the first putative conjugative plasmid in an obligate intracellular parasite. PLoS Biol. 2005;3(8):e248.

39. Horta MC, Labruna MB, Durigon EL, Schumaker TT. Isolation of Rickettsia felis in the mosquito cell line C6/36. Appl Environ Microbiol. 2006;72(2):1705-7.

40. Pornwiroon W, Pourciau SS, Foil LD, Macaluso KR. Rickettsia felis from cat fleas: isolation and culture in a tick-derived cell line. Appl Environ Microbiol. 2006;72(8):5589-95.

41. Thepparit C, Sunyakumthorn P, Guillotte ML, Popov VL, Foil LD, Macaluso KR. Isolation of a rickettsial pathogen from a non-hematophagous arthropod. PLoS One. 2011;6(1):e16396.

42. Yusuf M, Turner B. Characterisation of Wolbachia-like bacteria isolated from the parthenogenetic stored-product pest psocid Liposcelis bostrychophila (Badonnel) (Psocoptera). J Stored Prod Res. 2004;40(2):207-25.

43. Perotti MA, Clarke HK, Turner BD, Braig HR. Rickettsia as obligate and mycetomic bacteria. FASEB J. 2006;20(13):2372-4.

44. Gillespie JJ, Driscoll TP, Verhoeve VI, Utsuki T, Husseneder C, Chouljenko VN, et al. Genomic diversification in strains of Rickettsia felis isolated from different arthropods. Genome Biol Evol. 2015;7(1):35-56.

45. Fournier PE, Belghazi L, Robert C, Elkarkouri K, Richards AL, Greub G, et al. Variations of plasmid content in Rickettsia felis. PLoS One. 2008;3(5):e2289.

46. Baldridge GD, Burkhardt NY, Labruna MB, Pacheco RC, Paddock CD, Williamson PC, et al. Wide dispersal and possible multiple origins of low-copy-number plasmids in rickettsia species associated with blood-feeding arthropods. Appl Environ Microbiol. 2010;76(6):1718-31.

47. Fournier PE, Dumler JS, Greub G, Zhang J, Wu Y, Raoult D. Gene sequence-based criteria for identification of new rickettsia isolates and description of Rickettsia heilongjiangensis sp. nov. J Clin Microbiol. 2003;41(12):5456-65.

48. Medini D, Serruto D, Parkhill J, Relman DA, Donati C, Moxon R, et al. Microbiology in the post-genomic era. Nat Rev Micro. 2008;6(6):419-30.

49. Jiang J, Maina AN, Knobel DL, Cleaveland S, Laudisoit A, Wamburu K, et al. Molecular detection of Rickettsia felis and Candidatus Rickettsia asemboensis in fleas from human habitats, Asembo, Kenya. Vector Borne Zoonotic Dis. 2013;13(8):550-8. First report of Rickettsia felis and RFLO in a population of cat fleas.

50. Mediannikov O, Aubadie-Ladrix M, Raoult D. Candidatus 'Rickettsia senegalensis' in cat fleas in Senegal. New Microbes New Infections. 2015;3:24-8.

51. Jima DD, Luce-Fedrow A, Yang Y, Maina AN, Snesrud EC, Otiang E, et al. Whole-genome sequence of "Candidatus Rickettsia asemboensis" Strain NMRCii, isolated from fleas of Western Kenya. Genome Announcements. 2015;3(2):e00018-15.

52. Bechah Y, Capo C, Mege JL, Raoult D. Epidemic typhus. Lancet Infect Dis. 2008;8(7):417-26.

53. Morick D, Krasnov BR, Khokhlova IS, Gutierrez R, Gottlieb Y, Harrus S. Vertical nontransovarial transmission of Bartonella in fleas. Mol Ecol. 2013;22(18):4747-52.

54. Morick D, Krasnov BR, Khokhlova IS, Gottlieb Y, Harrus S. Investigation of Bartonella acquisition and transmission in Xenopsylla ramesis fleas (Siphonaptera: Pulicidae). Mol Ecol. 2011;20(13):2864-70. 
55. Hii SF, Abdad MY, Kopp SR, Stenos J, Rees RL, Traub RJ. Seroprevalence and risk factors for Rickettsia felis exposure in dogs from Southeast Queensland and the Northern Territory. Australia ParasitesVectors. 2013;6:159.

56. Hii SF, Kopp SR, Thompson MF, O'Leary CA, Rees RL, Traub RJ. Molecular evidence of Rickettsia felis infection in dogs from Northern Territory. Australia Parasites Vectors. 2011;4:198.

57. Giudice E, Di Pietro S, Alaimo A, Blanda V, Lelli R, Francaviglia F, et al. A molecular survey of Rickettsia felis in fleas from cats and dogs in Sicily (Southern Italy). PLoS One. 2014;9(9): e106820.

58. Hii SF, Kopp SR, Abdad MY, Thompson MF, O'Leary CA, Rees $\mathrm{RL}$, et al. Molecular evidence supports the role of dogs as potential reservoirs for Rickettsia felis. Vector Borne Zoonotic Dis. 2011;11(8):1007-12.

59. Segura F, Pons I, Miret J, Pla J, Ortuno A, Nogueras MM. The role of cats in the eco-epidemiology of spotted fever group diseases. Parasites Vectors. 2014;7:353.

60. Wei L, Kelly P, Ackerson K, Zhang J, El-Mahallawy HS, Kaltenboeck B, et al. First report of Babesia gibsoni in Central America and survey for vector-borne infections in dogs from Nicaragua. Parasites Vectors. 2014;7:126.

61. Horta MC, Ogrzewalska M, Azevedo MC, Costa FB, Ferreira F, Labruna MB. Rickettsia felis in Ctenocephalides felis felis from five geographic regions of Brazil. AmJTrop Med Hyg. 2014;91(1):96-100.

62. Panti-May JA, Torres-Castro M, Hernandez-Betancourt S, DzulRosado K, Zavala-Castro J, Lopez-Avila K, et al. Detection of Rickettsia felis in wild mammals from three municipalities in Yucatan. Mexico: EcoHealth; 2014.

63. Mourembou G, Fenollar F, Socolovschi C, Lemamy GJ, Nzoughe $\mathrm{H}$, Kouna LC, et al. Molecular detection of fastidious and common bacteria as well as Plasmodium spp. in febrile and afebrile children in Franceville, Gabon. AmJTrop Med Hyg. 2015;92(5):926-32.

64. Mediannikov O, Fenollar F, Bassene H, Tall A, Sokhna C, Trape JF, et al. Description of "yaaf", the vesicular fever caused by acute Rickettsia felis infection in Senegal. J Infect. 2013;66(6):536-40.

65. Mediannikov O, Socolovschi C, Million M, Sokhna C, Bassene H, Diatta G, et al. Molecular identification of pathogenic bacteria in eschars from acute febrile patients, Senegal. AmJTrop Med Hyg. 2014;91(5):1015-9.

66. Sokhna C, Mediannikov O, Fenollar F, Bassene H, Diatta G, Tall A, et al. Point-of-care laboratory of pathogen diagnosis in rural Senegal. PLoS Negl Trop Dis. 2013;7(1):e1999.

67. Labruna MB, Walker DH. Rickettsia felis and changing paradigms about pathogenic rickettsiae. Emerg Infect Dis. 2014;20(10): 1768-9.

68. Macaluso KR, Sonenshine DE, Ceraul SM, Azad AF. Rickettsial infection in Dermacentor variabilis (Acari: Ixodidae) inhibits transovarial transmission of a second Rickettsia. J Med Entomol. 2002;39(6):809-13.

69. Burgdorfer W, Hayes SF, Mavros AJ. Non-pathogenic rickettsiae in Dermacentor andersoni: a limiting factor for the distribution of Rickettsia rickettsii. In: Burgdorfer W, Anacker RL, editors. Rickettsiae and rickettsial diseases. New York: Academic Press, Inc; 1981. p. 585-94.

70. Noden BH, Radulovic S, Higgins JA, Azad AF. Molecular identification of Rickettsia typhi and R. felis in co-infected Ctenocephalides felis (Siphonaptera: Pulicidae). J Med Entomol. 1998;35(4):410-4.

71. Silaghi C, Knaus M Fau - Rapti D, Rapti D Fau - Shukullari E, Shukullari E Fau - Pfister K, Pfister K Fau - Rehbein S, Rehbein S. Rickettsia felis and Bartonella spp. in fleas from cats in Albania. 2012(1557-7759 (Electronic)).

72. Khaldi M, Socolovschi C, Benyettou M, Barech G, Biche M, Kernif $\mathrm{T}$, et al. Rickettsiae in arthropods collected from the
North African Hedgehog (Atelerix algirus) and the desert hedgehog (Paraechinus aethiopicus) in Algeria. Comp Immunol Microbiol Infect Dis. 2012;35(2):117-22.

73. Bitam I, Baziz B, Kernif T, Harrat Z, Parola P, Raoult D. Molecular detection of Rickettsia typhi and Rickettsia felis in fleas from Algeria. Clin Microbiol Infect. 2009;15 Suppl 2:255-6.

74. Barrs VR, Beatty JA, Wilson BJ, Evans N, Gowan R, Baral RM, et al. Prevalence of Bartonella species, Rickettsia felis, haemoplasmas and the Ehrlichia group in the blood of cats and fleas in eastern Australia. Aust Vet J. 2010;88(5):160-5.

75. Behar A, McCormick LJ, Perlman SJ. Rickettsia felis infection in a common household insect pest, Liposcelis bostrychophila (Psocoptera: Liposcelidae). Appl Environ Microbiol. 2010;76(7):2280-5.

76. Soares HS, Barbieri AR, Martins TF, Minervino AH, de Lima JT, Marcili A, et al. Ticks and rickettsial infection in the wildlife of two regions of the Brazilian Amazon. Exp Appl Acarol. 2015;65(1):125-40.

77. Milagres BS, Padilha AF, Barcelos RM, Gomes GG, Montandon CE, Pena DC, et al. Rickettsia in synanthropic and domestic animals and their hosts from two areas of low endemicity for Brazilian spotted fever in the eastern region of Minas Gerais, Brazil. AmJTrop Med Hyg. 2010;83(6):1305-7.

78. Gehrke FS, Gazeta GS, Souza ER, Ribeiro A, Marrelli MT, Schumaker TT. Rickettsia rickettsii, Rickettsia felis and Rickettsia sp. TwKM03 infecting Rhipicephalus sanguineus and Ctenocephalides felis collected from dogs in a Brazilian spotted fever focus in the State of Rio De Janeiro/Brazil. Clin Microbiol Infect. 2009;15 Suppl 2:267-8.

79. Abarca K, Lopez J, Acosta-Jamett G, Martinez-Valdebenito C. Rickettsia felis in Rhipicephalus sanguineus from two distant Chilean cities. Vector Borne Zoonotic Dis. 2013;13(8):607-9.

80. Fang W, Yao L, Cao X, Sun Y, Zhang X, Shao L, et al. First molecular detection of Rickettsia felis-like organism in Eulaelaps stabularis from the Changbai Mountain area of China. J Parasitol. 2015;101(5):514-9.

81. Zhang J, Lu G, Kelly P, Zhang Z, Wei L, Yu D, et al. First report of Rickettsia felis in China. BMC Infect Dis. 2014;14:682.

82. Ramirez-Hernandez A, Montoya V, Martinez A, Perez JE, Mercado M, de la Ossa A, et al. Molecular detection of Rickettsia felis in different flea species from Caldas, Colombia. AmJTrop Med Hyg. 2013;89(3):453-9.

83. Troyo A, Alvarez D, Taylor L, Abdalla G, Calderon-Arguedas O, Zambrano ML, et al. Rickettsia felis in Ctenocephalides felis from Guatemala and Costa Rica. AmJTrop Med Hyg. 2012;86(6): 1054-6.

84. Hun L, Troyo A, Taylor L, Barbieri AM, Labruna MB. First report of the isolation and molecular characterization of Rickettsia amblyommii and Rickettsia felis in Central America. Vector Borne Zoonotic Dis. 2011;11(10):1395-7.

85. Socolovschi C, Pages F, Ndiath MO, Ratmanov P, Raoult D. Rickettsia species in African Anopheles mosquitoes. PLoS One. 2012;7(10):e48254.

86. Christou C, Psaroulaki A, Antoniou M, Toumazos P, Ioannou I, Mazeris A, et al. Rickettsia typhi and Rickettsia felis in Xenopsylla cheopis and Leptopsylla segnis parasitizing rats in Cyprus. AmJTrop Med Hyg. 2010;83(6):1301-4.

87. Lawrence AL, Hii SF, Jirsova D, Panakova L, Ionica AM, Gilchrist K, et al. Integrated morphological and molecular identification of cat fleas (Ctenocephalides felis) and dog fleas (Ctenocephalides canis) vectoring Rickettsia felis in central Europe. Vet Parasitol. 2015;210(3-4):215-23.

88. Mediannikov O, Davoust B, Socolovschi C, Tshilolo L, Raoult D, Parola P. Spotted fever group rickettsiae in ticks and fleas from the Democratic Republic of the Congo. Ticks Tick-Borne Dis. 2012;3(5-6):371-3. 
89. Leulmi H, Socolovschi C, Laudisoit A, Houemenou G, Davoust B, Bitam I, et al. Detection of Rickettsia felis, Rickettsia typhi, Bartonella Species and Yersinia pestis in fleas (Siphonaptera) from Africa. PLoS Negl Trop Dis. 2014;8(10):e3152.

90. Kumsa B, Parola P, Raoult D, Socolovschi C. Molecular detection of Rickettsia felis and Bartonella henselae in dog and cat fleas in Central Oromia, Ethiopia. AmJTrop Med Hyg. 2014;90(3):457-62.

91. Mediannikov O, Abdissa A, Diatta G, Trape JF, Raoult D. Rickettsia felis in fleas, southern Ethiopia, 2010. Emerg Infect Dis. 2012;18(8):1385-6.

92. Pader V, Nikitorowicz Buniak J, Abdissa A, Adamu H, Tolosa T, Gashaw A, et al. Candidatus Rickettsia hoogstraalii in Ethiopian Argas persicus ticks. Ticks Tick-Borne Dis. 2012;3(5-6):338-45.

93. Marie JL, Davoust B, Socolovschi C, Raoult D, Parola P. Molecular detection of rickettsial agents in ticks and fleas collected from a European hedgehog (Erinaceus europaeus) in Marseilles, France. Comp Immunol Microbiol Infect Dis. 2012;35(1):77-9.

94. Marie JL, Davoust B, Socolovschi C, Mediannikov O, Roqueplo C, Beaucournu JC, et al. Rickettsiae in arthropods collected from red foxes (Vulpes vulpes) in France. Comp Immunol Microbiol Infect Dis. 2012;35(1):59-62.

95. Socolovschi C, Pages F, Raoult D. Rickettsia felis in Aedes albopictus mosquitoes, Libreville, Gabon. Emerg Infect Dis. 2012;18(10):1687-9.

96. Hornok S, Meli ML, Perreten A, Farkas R, Willi B, Beugnet F, et al. Molecular investigation of hard ticks (Acari: Ixodidae) and fleas (Siphonaptera: Pulicidae) as potential vectors of rickettsial and mycoplasmal agents. Vet Microbiol. 2010;140(1-2): 98-104.

97. Barbara KA, Farzeli A, Ibrahim IN, Antonjaya U, Yunianto A, Winoto I, et al. Rickettsial infections of fleas collected from small mammals on four islands in Indonesia. J Med Entomol. 2010;47(6):1173-8.

98. Torina A, Blanda V, Antoci F, Scimeca S, D'Agostino R, Scariano E, et al. A molecular survey of Anaplasma spp., Rickettsia spp., Ehrlichia canis and Babesia microti in foxes and fleas from Sicily. Transbound Emerg Dis. 2013;60 Suppl 2:125-30.

99. Capelli G, Montarsi F, Porcellato E, Maioli G, Furnari C, Rinaldi L, et al. Occurrence of Rickettsia felis in dog and cat fleas (Ctenocephalides felis) from Italy. Parasites Vectors. 2009;2 Suppl 1:S8.

100. Maioli G, Horta MC, Ogrzewalska M, Capelli G, Souza SO, Richtzenhain LJ, et al. First detection of Rickettsia felis in Ctenocephalides felis fleas from Italy. Clin Microbiol Infect. 2009;15 Suppl 2:222-3.

101. Berrelha J, Briolant S, Muller F, Rolain JM, Marie JL, Pages F, et al. Rickettsia felis and Rickettsia massiliae in Ivory Coast, Africa. Clin Microbiol Infect. 2009;15 Suppl 2:251-2.

102. Ko S, Kim HC, Yang YC, Chong ST, Richards AL, Sames WJ, et al. Detection of Rickettsia felis and Rickettsia typhi and seasonal prevalence of fleas collected from small mammals at Gyeonggi Province in the Republic of Korea. Vector Borne Zoonotic Dis. 2011;11(9):1243-51.

103. Varagnol M, Parola P, Jouan R, Beaucournu JC, Rolain JM, Raoult D. First detection of Rickettsia felis and Bartonella clarridgeiae in fleas from Laos. Clin Microbiol Infect. 2009;15 Suppl 2:334-5.

104. Mba PA, Marie JL, Rolain JM, Davoust B, Beaucournu JC, Raoult D, et al. Rickettsia felis and Bartonella henselae in fleas from Lebanon. Vector Borne Zoonotic Dis. 2011;11(7):991-2.

105. Rolain JM, Bitam I, Buffet S, Marie JL, Bourry O, Portelli-Clerc C, et al. Presence or absence of plasmid in Rickettsia felis depending on the source of fleas. Clin Microbiol Infect. 2009;15 Suppl 2:296-7.
106. Tay ST. Wolbachia endosymbionts, Rickettsia felis and Bartonella species, in Ctenocephalides felis fleas in a tropical region. J Vector Ecol. 2013;38(1):200-2.

107. Kernif T, Socolovschi C, Wells K, Lakim MB, Inthalad S, Slesak $\mathrm{G}$, et al. Bartonella and Rickettsia in arthropods from the Lao PDR and from Borneo, Malaysia. Comp Immunol Microbiol Infect Dis. 2012;35(1):51-7.

108. Peniche-Lara G, Dzul-Rosado K, Perez-Osorio C, Zavala-Castro J. Rickettsia typhi in rodents and R. felis in fleas in Yucatan as a possible causal agent of undefined febrile cases. Rev Inst Med Trop Sao Paulo. 2015;57(2):129-32.

109. Boudebouch N, Sarih M, Beaucournu JC, Amarouch H, Hassar $\mathrm{M}$, Raoult D, et al. Bartonella clarridgeiae, B. henselae and Rickettsia felis in fleas from Morocco. Ann Trop Med Parasitol. 2011;105(7):493-8.

110. Mediannikov O, Cabre O, Qu F, Socolovschi C, Davoust B, Marie $\mathrm{JL}$, et al. Rickettsia felis and Bartonella clarridgeiae in fleas from New Caledonia. Vector Borne Zoonotic Dis. 2011;11(2):181-3.

111. Tijsse-Klasen E, Fonville M, Gassner F, Nijhof AM, Hovius EK, Jongejan F, et al. Absence of zoonotic Bartonella species in questing ticks: first detection of Bartonella clarridgeiae and Rickettsia felis in cat fleas in the Netherlands. Parasites Vectors. 2011;4:61.

112. Bermudez CS, Zaldivar AY, Spolidorio MG, Moraes-Filho J, Miranda RJ, Caballero CM, et al. Rickettsial infection in domestic mammals and their ectoparasites in El Valle de Anton, Cocle. Panama Vet Parasitol. 2011;177(1-2):134-8.

113. Flores-Mendoza C, Florin D, Felices V, Pozo EJ, Graf PC, Burrus RG, et al. Detection of Rickettsia parkeri from within Piura, Peru, and the first reported presence of Candidatus Rickettsia andeanae in the tick Rhipicephalus sanguineus. Vector Borne Zoonotic Dis. 2013;13(7):505-8.

114. Dieme C, Parola P, Guernier V, Lagadec E, Le Minter G, Balleydier E, et al. Rickettsia and Bartonella species in fleas from Reunion Island. AmJTrop Med Hyg. 2015;92(3):617-9.

115. Spitalska E, Boldis V, Mosansky L, Sparagano O, Stanko M. Rickettsia species in fleas collected from small mammals in Slovakia. Parasitol Res. 2015;114(11):4333-9.

116. Nogueras MM, Pons I, Ortuno A, Miret J, Pla J, Castella J, et al. Molecular detection of Rickettsia typhi in cats and fleas. PLoS One. 2013;8(8):e71386.

117. Nogueras MM, Pons I, Ortuno A, Lario S, Segura F. Rickettsia felis in fleas from Catalonia (Northeast Spain). Vector Borne Zoonotic Dis. 2011;11(5):479-83.

118. Lledo L, Gimenez-Pardo C, Dominguez-Penafiel G, Sousa R, Gegundez MI, Casado N, et al. Molecular detection of hemoprotozoa and Rickettsia species in arthropods collected from wild animals in the Burgos Province, Spain. Vector Borne Zoonotic Dis. 2010;10(8):735-8.

119. Hsu YM, Lin CC, Chomel BB, Tsai KH, Wu WJ, Huang CG, et al. Identification of Rickettsia felis in fleas but not ticks on stray cats and dogs and the evidence of Rickettsia rhipicephali only in adult stage of Rhipicephalus sanguineus and Rhipicephalus haemaphysaloides. Comp Immunol Microbiol Infect Dis. 2011;34(6):513-8.

120. Tsai KH, Huang CG, Fang CT, Shu PY, Huang JH, Wu WJ. Prevalence of Rickettsia felis and the first identification of Bartonella henselae Fizz/CAL-1 in cat fleas (Siphonaptera: Pulicidae) from Taiwan. J Med Entomol. 2011;48(2):445-52.

121. Kuo CC, Huang JL, Lin TE, Wang HC. Detection of Rickettsia spp. and host and habitat associations of fleas (Siphonaptera) in eastern Taiwan. Med Vet Entomol. 2012;26(3):341-50.

122. Khrouf F, M'Ghirbi Y, Znazen A, Ben Jemaa M, Hammami A, Bouattour A. Detection of Rickettsia in Rhipicephalus sanguineus ticks and Ctenocephalides felis fleas from southeastern Tunisia by reverse line blot assay. J Clin Microbiol. 2014;52(1):268-74. 
123. Znazen A, Khrouf F, Elleuch N, Lahiani D, Marrekchi C, M'Ghirbi Y, et al. Multispacer typing of Rickettsia isolates from humans and ticks in Tunisia revealing new genotypes. Parasites Vectors. 2013;6:367.

124. Gargili A, Palomar AM, Midilli K, Portillo A, Kar S, Oteo JA. Rickettsia species in ticks removed from humans in Istanbul, Turkey. Vector Borne Zoonotic Dis. 2012;12(11):938-41.

125. Abramowicz KF, Wekesa JW, Nwadike CN, Zambrano ML, Karpathy SE, Cecil D, et al. Rickettsia felis in cat fleas, Ctenocephalides felis parasitizing opossums, San Bernardino County, California. Med Vet Entomol. 2012;26(4):458-62.

126. Eremeeva ME, Karpathy SE, Krueger L, Hayes EK, Williams AM, Zaldivar Y, et al. Two pathogens and one disease: detection and identification of flea-borne Rickettsiae in areas endemic for murine typhus in California. J Med Entomol. 2012;49(6):1485-94.

127. Jiang J, Stromdahl EY, Richards AL. Detection of Rickettsia parkeri and Candidatus Rickettsia andeanae in Amblyomma maculatum Gulf Coast ticks collected from humans in the United States. Vector Borne Zoonotic Dis. 2012;12(3):175-82.

128. Mattila JT, Burkhardt NY, Hutcheson HJ, Munderloh UG, Kurtti TJ. Isolation of cell lines and a rickettsial endosymbiont from the soft tick Carios capensis (Acari: Argasidae: Ornithodorinae). J Med Entomol. 2007;44(6):1091-101.

129. Karpathy SE, Hayes EK, Williams AM, Hu R, Krueger L, Bennett $\mathrm{S}$, et al. Detection of Rickettsia felis and Rickettsia typhi in an area of California endemic for murine typhus. Clin Microbiol Infect. 2009;15 Suppl 2:218-9.

130. Lappin MR, Hawley J. Presence of Bartonella species and Rickettsia species DNA in the blood, oral cavity, skin and claw beds of cats in the United States. Vet Dermatol. 2009;20(5-6):509-14.

131. Venzal JM, Perez-Martinez L, Felix ML, Portillo A, Blanco JR, Oteo JA. Prevalence of Rickettsia felis in Ctenocephalides felis and Ctenocephalides canis from Uruguay. Ann N Y Acad Sci. 2006;1078:305-8.

132. Kelly PJ, Lucas H, Eremeeva ME, Dirks KG, Rolain JM, Yowell $\mathrm{C}$, et al. Rickettsia felis, West Indies. Emerg Infect Dis. 2010;16(3):570-1

133. Duh D, Punda-Polic V, Trilar T, Petrovec M, Bradaric N, AvsicZupanc T. Molecular identification of Rickettsia felis-like bacteria in Haemaphysalis sulcata ticks collected from domestic animals in southern Croatia. Ann N Y Acad Sci. 2006;1078:347-51.

134. Oteo JA, Portillo A, Portero F, Zavala-Castro J, Venzal JM, Labruna MB. Candidatus Rickettsia asemboensis' and Wolbachia spp. in Ctenocephalides felis and Pulex irritans fleas removed from dogs in Ecuador. Parasites Vectors. 2014;7: 455.

135. Loftis AD, Reeves WK, Szumlas DE, Abbassy MM, Helmy IM, Moriarity JR, et al. Surveillance of Egyptian fleas for agents of public health significance: Anaplasma, Bartonella, Coxiella, Ehrlichia, Rickettsia, and Yersinia pestis. AmJTrop Med Hyg. 2006;75(1):41-8.

136. Reeves WK, Loftis AD, Szumlas DE, Abbassy MM, Helmy IM, Hanafi HA, et al. Rickettsial pathogens in the tropical rat mite Ornithonyssus bacoti (Acari: Macronyssidae) from Egyptian rats (Rattus spp.). Exp Appl Acarol. 2007;41(1-2):101-7.

137. Gilles J, Silaghi C, Just FT, Pradel I, Pfister K. Polymerase chain reaction detection of Rickettsia felis-like organism in Archaeopsylla erinacei (Siphonaptera: Pulicidae) from Bavaria, Germany. J Med Entomol. 2009;46(3):703-7.
138. Chahota R, Thakur SD, Sharma M, Mittra S. Detection of fleaborne Rickettsia species in the Western Himalayan region of India. Indian J Med Microbiol. 2015;33(3):422-5.

139. Hii SF, Lawrence AL, Cuttell L, Tynas R, Abd Rani PA, Slapeta J, et al. Evidence for a specific host-endosymbiont relationship between 'Rickettsia sp. genotype RF2125' and Ctenocephalides felis orientis infesting dogs in India. Parasites Vectors. 2015;8:169.

140. Weinert LA, Werren JH, Aebi A, Stone GN, Jiggins FM. Evolution and diversity of Rickettsia bacteria. BMC Biol. 2009;7:6.

141. Rzotkiewicz S, Gutierrez R, Krasnov BR, Morick D, Khokhlova IS, Nachum-Biala Y, et al. Novel evidence suggests that a 'Rickettsia felis-like' organism is an endosymbiont of the desert flea. Xenopsylla Ramesis Mol Ecol. 2015;24(6):1364-73.

142. Reeves WK, Durden LA, Iwakami M, Vince KJ, Paul RR. Rickettsial diseases and ectoparasites from military bases in Japan. J Parasitol. 2015;101(2):150-5.

143. Luce-Fedrow A, Maina AN, Otiang E, Ade F, Omulo S, Ogola E, et al. Isolation of Candidatus Rickettsia asemboensis from Ctenocephalides fleas. Vector Borne Zoonotic Dis. 2015;15(4):268-77.

144. Mokhtar AS, Tay ST. Molecular detection of Rickettsia felis, Bartonella henselae, and B. clarridgeiae in fleas from domestic dogs and cats in Malaysia. AmJTrop Med Hyg. 2011;85(5): 931-3.

145. Forshey BM, Stewart A, Morrison AC, Galvez H, Rocha C, Astete $\mathrm{H}$, et al. Epidemiology of spotted fever group and typhus group rickettsial infection in the Amazon basin of Peru. AmJTrop Med Hyg. 2010;82(4):683-90.

146. Milhano N, Palma M, Marcili A, Nuncio MS, de Carvalho IL, de Sousa R. Rickettsia lusitaniae sp. nov. isolated from the soft tick Ornithodoros erraticus (Acarina: Argasidae). Comp Immunol Microbiol Infect Dis. 2014;37(3):189-93.

147. Roucher C, Mediannikov O, Diatta G, Trape JF, Raoult D. A new Rickettsia species found in fleas collected from human dwellings and from domestic cats and dogs in Senegal. Vector Borne Zoonotic Dis. 2012;12(5):360-5.

148. Mediannikov O, Audoly G, Diatta G, Trape JF, Raoult D. New Rickettsia sp. in tsetse flies from Senegal. Comp Immunol Microbiol Infect Dis. 2012;35(2):145-50.

149. Blanco JR, Perez-Martinez L, Vallejo M, Santibanez S, Portillo A, Oteo JA. Prevalence of Rickettsia felis-like and Bartonella Spp. in Ctenocephalides felis and Ctenocephalides canis from La Rioja (Northern Spain). Ann N Y Acad Sci. 2006;1078:270-4.

150. Tsui PY, Tsai KH, Weng MH, Hung YW, Liu YT, Hu KY, et al. Molecular detection and characterization of spotted fever group rickettsiae in Taiwan. AmJTrop Med Hyg. 2007;77(5):883-90.

151. Foongladda S, Inthawong D, Kositanont U, Gaywee J. Rickettsia, Ehrlichia, Anaplasma, and Bartonella in ticks and fleas from dogs and cats in Bangkok. Vector Borne Zoonotic Diseases. 2011;11(10):1335-41.

152. Parola P, Sanogo OY, Lerdthusnee K, Zeaiter Z, Chauvancy G, Gonzalez JP, et al. Identification of Rickettsia spp. and Bartonella spp. in ffrom the Thai-Myanmar border. Ann N Y Acad Sci. 2003;990:173-81.

153. Reeves WK, Nelder MP, Korecki JA. Bartonella and Rickettsia in fleas and lice from mammals in South Carolina, U.S.A. J Vector Ecol. 2005;30(2):310-5.

154. Nelder MP, Reeves WK, Adler PH, Wozniak A, Wills W. Ectoparasites and associated pathogens of free-roaming and captive animals in zoos of South Carolina. Vector Borne Zoonotic Dis. 2009;9(5):469-77. 